\title{
Ultrasound Effect on Gene Expression of Sex Determining Region Y-box 9 (SOX9) and Transforming Growth Factor $\beta$ Isoforms in Adipose Stem Cells
}

\author{
Hajar Shafaei, ${ }^{1, *}$ and Hassan Baghernezhad ${ }^{2}$ \\ ${ }^{1}$ Department of Anatomical Sciences, Faculty of Medicine, Tabriz University of Medical Sciences, Tabriz, IR Iran \\ ${ }^{2}$ Department of Radiology, Sina Hospital, Tabriz University of Medical Sciences, Tabriz, IR Iran \\ "Corresponding author: Hajar Shafaei, Department of Anatomical Sciences, Faculty of Medicine, Tabriz University of Medical Sciences, Tabriz, IR Iran. E-mail: \\ shafaei49@gmail.com
}

Received 2015 February 14; Accepted 2015 July 3.

\begin{abstract}
Background: Cartilage tissue engineering is a promising method for repair of cartilage defects. Induction of chondrogenesis in mesenchymal stem cells (MSC) is currently used in cartilage tissue engineering. Among growth factors, transforming growth factor $\beta$ (TGF- $\beta$ ) is common chondrogenic inducer but toward hypertrophic chondrocyte. However, mechanical factors such as ultrasound could stimulate chondrogenesis.

Objectives: We aimed to investigate stimulation of endogenous TGF- $\beta$ genes expression by low intensity pulsed ultrasound (LIPUS) in MSC.

Materials and Methods: In this experimental study, adipose tissue stem cells (ASC) cultures were treated with or without LIPUS (30 $\mathrm{mW} / \mathrm{cm}^{2}, 20 \mathrm{~min} /$ day) and with or without TGF- $\beta 3(10 \mathrm{ng} / \mathrm{mL})$ for 4 or 14 days. Chondrogenic gene expression of SOX 9 and members of TGF- $\beta$ family ( $\beta 1, \beta 2$ and $\beta 3$ ) was assessed in ASC cultures at day 4 and 14 by real time PCR.

Results: The gene expression of SOX9 significantly increased by LIPUS and TGF- $\beta$ treatment versus control cultures. Exogenous TGF$\beta 3$ treatment stimulated endogenous TGF- $\beta 1$ and $\beta 2$ gene expressions more than LIPUS treated cultures at day 4 . LIPUS, TGF- $\beta$ and LIPUS plus TGF- $\beta$ treated cultures expressed same TGF- $\beta 3$ gene expression at day 4 . The expression of TGF- $\beta 1$ and $\beta 2$ decreased by LIPUS in comparison to TGF- $\beta$ treated cultures at day 14 .

Conclusions: Our results suggest that LIPUS might initiate differentiation of ASC without enhancing endogenous TGF- $\beta$ genes in in-vitro.
\end{abstract}

Keywords: Adipose Stem Cells, Chondrogenesis, Cartilage Tissue Engineering, Ultrasound, Transforming Growth Factor- $\beta$

\section{Background}

mesenchymal stem cells (MSC) are currently evaluated for their use in cartilage tissue engineering approaches. Adipose stem cells as a kind of MSC have been used most frequently for chondrogenic induction. Transforming growth factor $\beta$ (TGF- $\beta$ ) and mechanical loading are used to promote chondrogenic differentiation of stem cells [1] and the application of these factors for chondrogenic induction are taken from embryonic development knowledge and transforming growth factor- $\beta$ (TGF- $\beta$ ) is the key regulator of cartilage formation [2]. Three members of TGF- $\beta$ ( $\beta 1, \beta 2$ and $\beta 3)$ are involved in chondrogenesis of MSC. Several studies have found that TGF- $\beta$ stimulates chondrogenic gene and protein expression in MSC differentiation [3-5]. TGF- $\beta$ could induce chondrogenic differentiation of MSC [1], but several disadvantages are associated with its use such as the formation of an unfavourable hypertrophic cartilage phenotype which followed by endo- chondral ossification instead of permanent chondrogenesis [6-9]. Mechanical loading induces chondrogenic differentiation of bone marrow mesenchymal stem cells (BMSCs) as effective as TGF- $\beta[10,11]$ and it might enhance TGF- $\beta$ receptors and also influences on TGF- $\beta$ intracellular pathway molecules [12]. However the effects of loading on expression of endogenous TGF- $\beta$ are not investigated.

TGF- $\beta$ is potent growth factor in proliferation and differentiation of cells [13] and using of this growth factor for clinical cartilage tissue engineering which it is not approved by FDA. Also TGF- $\beta$ might promote in vitro chondrogenesis toward hypertrophic chondrocytes [14]. However, direct mechanical stimulation without using exogenous TGF- $\beta$ is one potential strategy to optimize chondrogenesis in order to improve the functional outcome of MSCbased constructs $[4,15]$. Among mechanical loading types low intensity pulsed ultrasound (LIPUS) is used for chondrogenic differentiation of MSC [16] and it is currently applying for rehabilitation in clinic. 


\section{Objectives}

For clinical purposes, it is necessary to show ultrasound dose not induce chondrogenesis via stimulation of TGF- $\beta$ expression and consequent unwanted hypertrophic chondrocytes formation. Therefore this study aimed to evaluate the effects of LIPUS on TGF- $\beta$ genes expression.

\section{Materials and Methods}

\subsection{Cell Isolation and Culture}

In this experimental study, adipose tissue stem cells (ASC) were isolated from subcutaneous adipose tissue that was harvested from patients undergoing elective surgical procedures, as previously described with minor modifications [17]. Informed consent and local ethical committee approval was obtained for the use of adipose tissue specimens for this research. Briefly, the obtained adipose tissue was washed with phosphate-buffered saline (PBS, Sigma) to remove red blood cells, chopped into small pieces and the extracellular matrix was digested for 60 minutes at $37^{\circ} \mathrm{C}$ with $0.5 \mathrm{U} / \mathrm{mL}$ Liberase Blendzyme 3 (Roche, The Netherlands) in PBS. A single cell suspension was obtained by filtering the digested material through a $100 \mu \mathrm{m}$ mesh filter to remove tissue debris. The ASC-containing cell suspension was centrifuged at $600 \mathrm{~g}$, and the pellet was resuspended in culture medium, which was composed of Dulbecco's modified Eagle's medium (DMEM, Invitrogen, UK) supplemented with $500 \mu \mathrm{g} / \mathrm{mL}$ streptomycin sulfate (Sigma), $600 \mu \mathrm{g} / \mathrm{mL}$ penicillin (Sigma) and 5\% platelet lysate. The ASC-containing cell suspension was cultured at $37^{\circ} \mathrm{C}$ and $5 \% \mathrm{CO}_{2}$ in a humidified incubator. After 24 - 48 hours media of cultures were changed to remove unattached cells. Medium was refreshed twice per week. Micromass cultures were established as $50 \mu$ L droplets containing $4 \times 10^{5}$ cells in 6-well culture dishes. Cultures were allowed to attach for 1 hour at $37^{\circ} \mathrm{C}$.

\subsection{Chondrogenic Differentiation of ASC}

Cultures were treated with LIPUS (as described below), TGF- $\beta 3$ (10 ng/mL) (Biovision, Milpitas, CA, USA) and the combination of LIPUS and TGF- $\beta 3$ (LIPUS + TGF- $\beta$ ). Cultures received DMEM supplemented with $1 \% \mathrm{FBS}, 100 \mathrm{U} / \mathrm{mL}$ penicillin, $100 \mu \mathrm{g} / \mathrm{mL}$ streptomycin and $2.5 \mu \mathrm{g} / \mathrm{mL}$ amphotericin $\mathrm{B}$.

\subsection{Low-Intensity Pulsed Ultrasound Treatment}

ASC cultures were exposed to LIPUS $\left(30 \mathrm{~mW} / \mathrm{cm}^{2}\right)$ during 20 minutes per day for a period of 4 or 14 days. The therapy unit consisted of two sonic accelerated fracture healing system devices (SAFHS®, model 2A; Exogen, Smith and Nephew Inc., Memphis, TN, USA) and three transducers per device, which were connected by coupling gel to the six-well culture plate. The SAFHS $®$ device provides lowintensity ultrasound at $1.5 \mathrm{MHz}$ frequency. This setting was used in earlier experiments by Smith and Nephew Inc. and has proven to provide ultrasonic waves in the medium. The distance between the transducer and the cultures was less than $2 \mathrm{~mm}$ [18]. Control culture plates were kept under identical conditions in 6-well culture dishes, but were not exposed to LIPUS treatment.

\subsection{Chondrogenic Gene Expression of Cultures}

RNA isolation was performed using TRIzol $®$ reagent (Invitrogen, Carlsbad, CA, USA). cDNA synthesis was performed using Superscript Vilo® (Invitrogen, Carlsbad, CA, USA). Real-time PCR reactions were performed using the SYBR Green reaction kit in a Light Cycler 480 (Roche Diagnostics). cDNA was used in $10 \mu \mathrm{L}$ PCR mix (Light Cycler DNA Master Fast start ${ }^{\text {plus }}$ kit, Roche Diagnostics) containing a final concentration of $0.5 \mathrm{pmol}$ of primers. Relative gene expression of chondrogenic differentiation master gene, SOX9 and TGF- $\beta$ isoforms ( $\beta 1, \beta 2$ and $\beta 3$ ) were determined. Using the Light Cycler software version 4 , the crossing points were assessed and plotted versus a serial dilution of individual gene standards using the Fit Points method. PCR efficiency was calculated, and only data with efficiencies ranging from 1.85 - 2.0 were used.

\subsection{Statistical Analysis}

Data were obtained from three independent experiments. Data were log transformed, normalized to the housekeeping gene and tested for statistical significance by one-way analysis of variance using Graph Pad prism 5 software. Data are expressed as mean \pm SEM. Differences are significant if $\mathrm{P}<0.05$.

\section{Results}

The histological evaluation of ASC cultures showed the production of cartilage extracellular matrix after 14 days. Proteoglycans production evaluated by alcian blue staining (Figure 1). Production of proteoglycans has been occurred by TGF- $\beta$ and LIPUS (Figure $1 \mathrm{~B}$ and $1 \mathrm{C}$ ) in comparison with control cultures (Figure $1 \mathrm{~A}$ ). Combination of inducers (TGF- $\beta$ and LIPUS) showed more alcian blue staining (Figure 1D). Cartilage of mouse trachea is used for positive control (Table 1).

The master gene of chondrogenesis, SOX9 significantly $(\mathrm{P}<0.005)$ expressed in LIPUS and TGF- $\beta$ treated cultures in comparison to control cultures at day 14 (Figure 2). The 
Table 1. Real Time PCR Primers Used in This Study

\begin{tabular}{|c|c|}
\hline Primer & Primer Sequence \\
\hline HPRT1F & 5'-GCTGACCTGCTGGATTACAT-3' \\
\hline HPRT1R & 5'-CTTGCGACCTTGACCATCT-3' \\
\hline SOX9F & 5'-CCCAACGCCATCTTCAAGG-3' \\
\hline SOX9R & 5'-CTGCTCAGCTCGCCGATGT-3' \\
\hline TGF- $\beta$ 1R & 5'-GGTGTTGAGCCCTTTCCAG-3' \\
\hline TGF- $\beta \mathbf{2 F}$ & 5'-ATCGATGGCACCTCCACATATG-3' \\
\hline TGF- $\beta$ 2 R & 5'-GCGAAGGCAGCAATTATGCTG-3' \\
\hline TGF- $\beta 3 \mathbf{F}$ & 5'-AAGCGCACAGAGCAGAGAATC-3' \\
\hline TGF- $\beta$ 3 R & 5'-AGTGTCAGTGACATCGAAG-3' \\
\hline
\end{tabular}

Abbreviations: $\mathrm{F}$, forward; HRPT1, hypoxanthine phosphoribosyltransferase as housekeeping gene; $\mathrm{R}$, reverse; SOX9, SRY (sex determining region Y)-box 9; TGF- $\beta$, trans forming growth factor- $\beta$.

Figure 1. Micrographs of Alcian Blue Staining for Proteoglycans Production by ASCs After 14 Days of Culture and Hyaline Cartilage

A
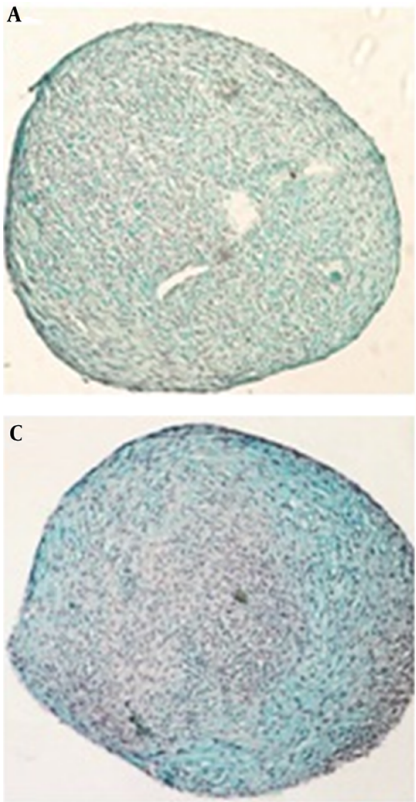

B
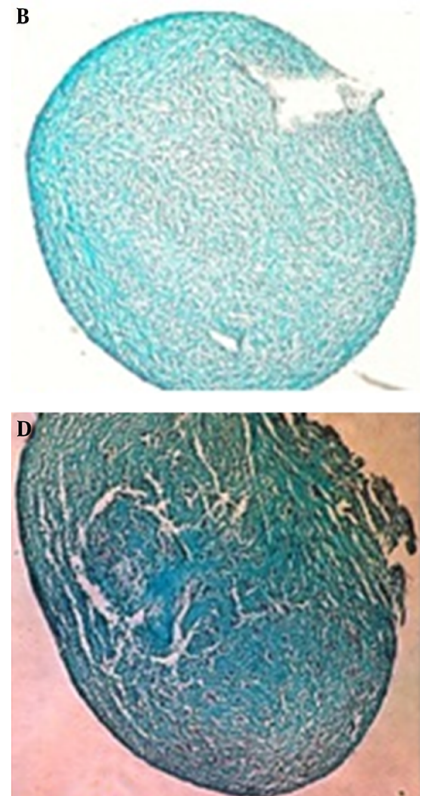

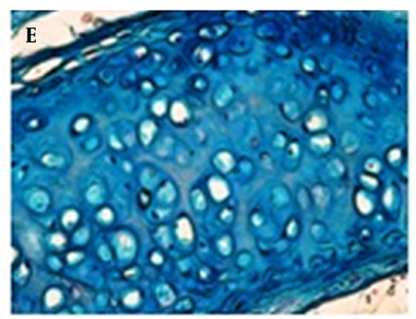

$\mathrm{A}$, Control cultures; $\mathrm{B}$, cultures treated with low-intensity ultrasound; C, TGF- $\beta$ treated pellets; D, low-intensity ultrasound in combination with TGF- $\beta$; E, hyaline cartilage as a positive control. 


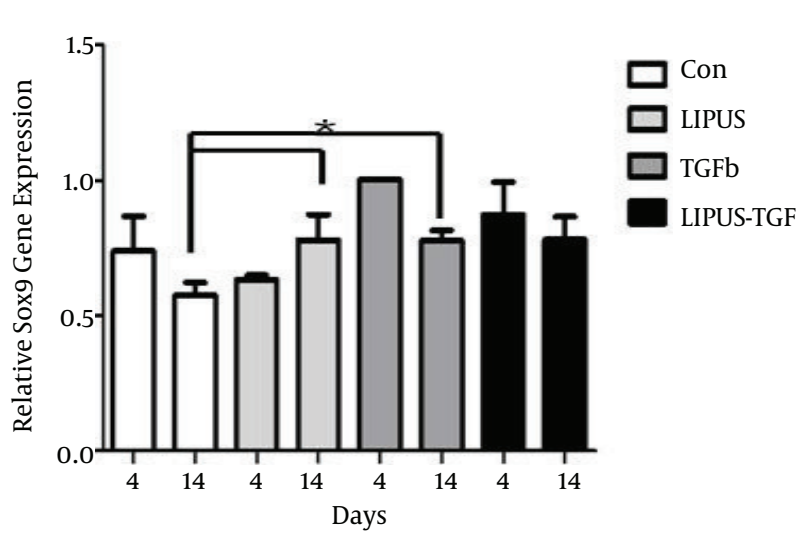

Figure 2. Effects of LIPUS, TGF- $\beta$, and Their Combination on SOX9 Gene Expression in ASC at Day 4 and 14

Figure 3. Effects of LIPUS, TGF- $\beta$ and Their Combination on TGF- $\beta$ Genes Expression in ASC at Day 4 and 14

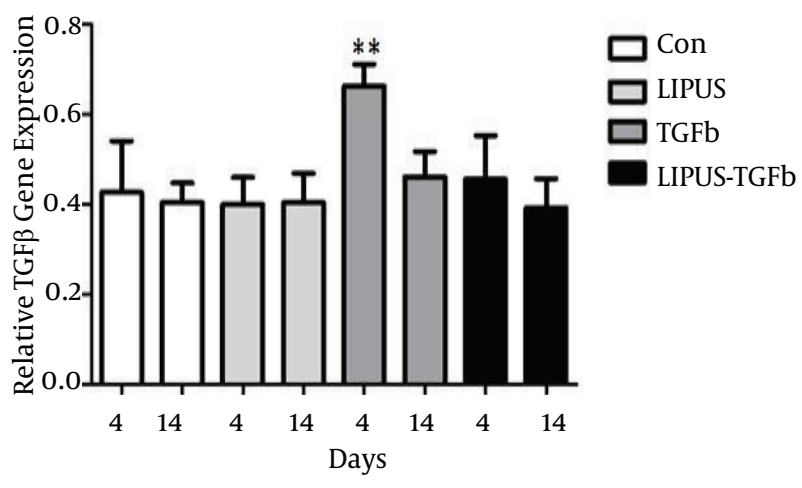

*Significantly different from control; * $\mathrm{P}<0.05$. LIPUS, low-intensity pulsed ultrasound; TGF- $\beta$, transforming growth factor- $\beta$.

gene expression results of endogenous TGF- $\beta$ showed significant expression by exogenous TGF- $\beta$ at day 4 (Figure 3 ). The expression of different isoforms of endogenous TGF- $\beta$ genes increased by TGF- $\beta$ treatment at day 4 (Figure 4A). However TGF- $\beta$ expression did not increased by LIPUS, TGF$\beta$ and both of them at day 14 (Figure 4B).

\section{Discussion}

In this study I showed that LIPUS increased the expression of SOX9 the same as TGF- $\beta$ treated cultures. However LIPUS did not change endogenous TGF- $\beta$ gene expressions in ASC in comparison to exogenous TGF- $\beta$. Our findings are in agreement with $\mathrm{Li}$ et al. results that stress could stimulate chondrogenesis in percence of inhibition of TGF pathway in MSC [19]. Addition of mechanical loading to chondrogenic medium may enhance chondrogenesis potential of mesenchymal stem cell [10]. Mechanical loading might change cell shape and facilities translocation of TGF- $\beta$ pathway molecules from cytoplasm to the nucleus and direct effect of TGF- $\beta$ or its receptors may interact with mechanical chondrogenic stimulation [12]. The interaction between mechanical loading and TGF- $\beta$ could be via various direct or indirect mechanisms. TGF- $\beta$ increases mechanosensitive proteins, paxillin and focal adhesion kinase and make cells sensitive to mechanical loading [20, 21]. In our study the high expression of SOX9 and TGF- $\beta$ indicates ultrasound may act via TGF- $\beta$ pathway and lower TGF- $\beta$ expression suggested involving TGF- $\beta$ receptors and other pathways. The results of pervious study showed that compressive loading increased in TGF- $\beta 1$ gene expression [12]. In the culture medium without TGF- $\beta 1$, mechanical loading stimulated gene and protein expression of TGF- $\beta 1$ and TGF- $\beta 3$ [22]. TGF- $\beta$ signaling may magnify the sensitivity of cells to mechanical forces by increasing of transcriptional factors such as SOX9 as a master gene of chondrgenesis. Inhibition of TGF- $\beta$ signaling pathway significantly decreased the stress-induced chondrogenic gene expressions [19]. Several studies have proposed that mechanical loading may stimulate TGF- $\beta$ signaling and promotes the chondrogenesis of MSCs $[11,12,23]$ but this study for first time is done TGF- $\beta$ gene expression isoforms by LIPUS treatment.

LIPUS may affect focal adhesion kinase an ERK mechanotransduction pathway and increased ECM production in chondrocytes [24]. TGF- $\beta$ and LIPUS act via c-Jun and ERK intracelluar pathway [25]. In this study even though there is no prominent increase in TGF- $\beta$ genes and SOX9 in combination of ultrasound and TGF- $\beta$ treatments. The high expression of SOX9 in ultrasound treatments in comparison with control cultures at day 4 and 14 in this study might be due to modulation of mechanotransduction by stage dependent TGF- $\beta$ signaling pathway [26].

Taken together, our data suggest that ultrasound could not induce endogenous TGF- $\beta$ gene expressions but mechanical stress produced TGF- $\beta 1$ to promote chondrogenesis [10]. Further studies on TGF- $\beta$ receptors would be necessary to elucidate the signaling pathway of ultrasound for chondrogenesis induction in MSC.

\section{Acknowledgments}

The author would to thanks Abolghasem Esmaeili for helping to do real time RT PCR.

\section{Footnote}

Funding/Support: This study is supported by grant of the Tabriz University of Medical Sciences (5/104/614). 
Figure 4. Effects of LIPUS, TGF- $\beta$ and Their Combination on TGF- $\beta 1,2$ and 3 Genes Expression in ASC at A, Day 4 and B, Day 14

A

Day 4

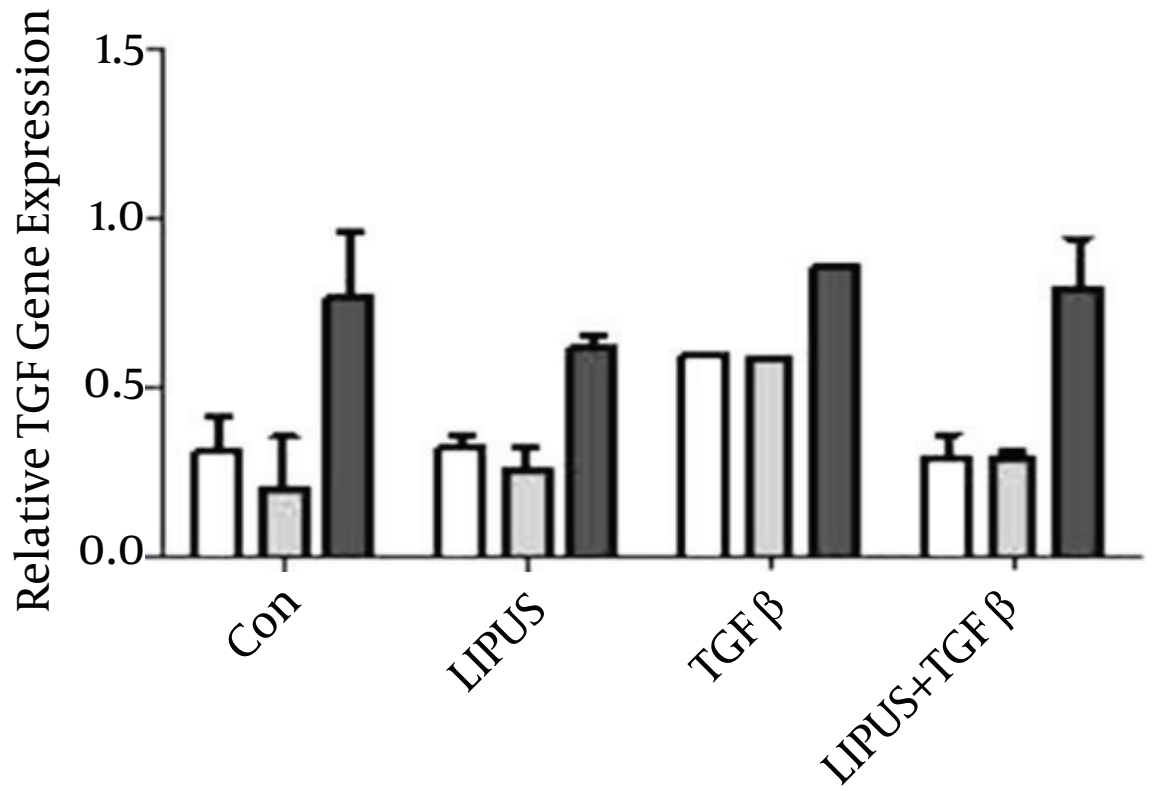

$\square$ TGF $\beta 1$

$\square$ TGF $\beta 2$

$\square$ TGF $\beta 3$

B

Day 14

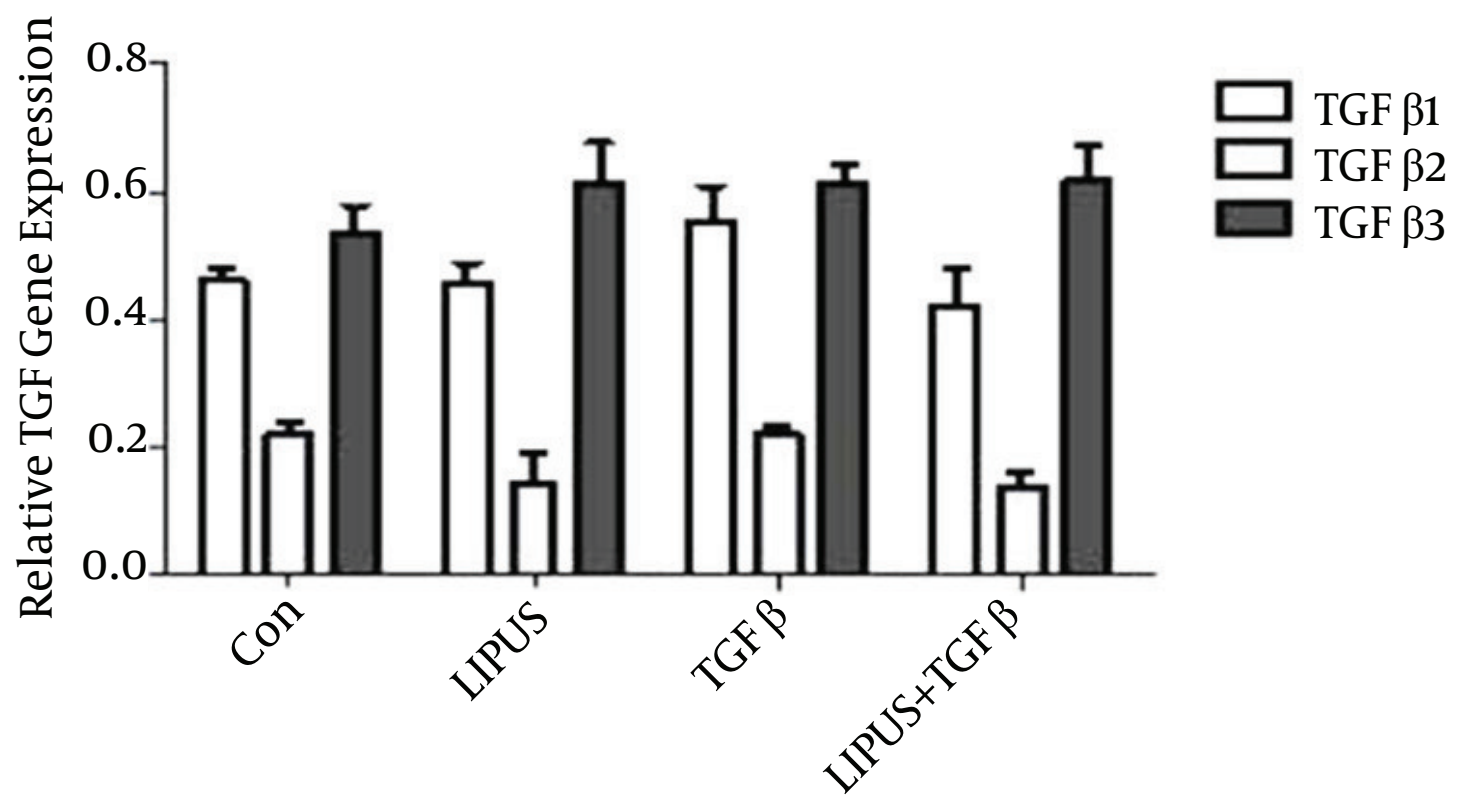

*Significantly different from control, ${ }^{*} \mathrm{P}<0.05$. LIPUS, low-intensity pulsed ultrasound; TGF- $\beta$, transforming growth factor- $\beta$. 


\section{References}

1. Schugar RC, Robbins PD, Deasy BM. Small molecules in stem cell self-renewal and differentiation. Gene Ther. 2008;15(2):126-35. doi: 10.1038/sj.gt.3303062. [PubMed:17989703].

2. Goldring MB, Tsuchimochi K, Ijiri K. The control of chondrogenesis. J Cell Biochem. 2006;97(1):33-44. doi: 10.1002/jcb.20652. [PubMed: 16215986].

3. Hao J, Varshney RR, Wang DA. Engineering osteogenesis and chondrogenesis with gene-enhanced therapeutic cells. Curr Opin Mol Ther. 2009;11(4):404-10. [PubMed: 19649985].

4. Huang AH, Farrell MJ, Mauck RL. Mechanics and mechanobiology of mesenchymal stem cell-based engineered cartilage. J Biomech. 2010;43(1):128-36. doi: 10.1016/j.jbiomech.2009.09.018. [PubMed: 19828149].

5. Nowlan NC, Sharpe J, Roddy KA, Prendergast PJ, Murphy P. Mechanobiology of embryonic skeletal development: Insights from animal models. Birth Defects Res C Embryo Today. 2010;90(3):203-13. doi: 10.1002/bdrc.20184. [PubMed: 20860060].

6. Winter A, Breit S, Parsch D, Benz K, Steck E, Hauner H, et al. Cartilagelike gene expression in differentiated human stem cell spheroids: a comparison of bone marrow-derived and adipose tissue-derived stromal cells. Arthritis Rheum. 2003;48(2):418-29. doi: 10.1002/art.10767. [PubMed: 12571852].

7. Sekiya I, Vuoristo JT, Larson BL, Prockop DJ. In vitro cartilage formation by human adult stem cells from bone marrow stroma defines the sequence of cellular and molecular events during chondrogenesis. Proc Natl Acad Sci U S A. 2002;99(7):4397-402. doi: 10.1073/pnas.052716199. [PubMed: 11917104].

8. Mwale F, Girard-Lauriault PL, Wang HT, Lerouge S, Antoniou J, Wertheimer MR. Suppression of genes related to hypertrophy and osteogenesis in committed human mesenchymal stem cells cultured on novel nitrogen-rich plasma polymer coatings. Tissue Eng. 2006;12(9):2639-47. doi: 10.1089/ten.2006.12.2639. [PubMed: 16995797].

9. Mueller MB, Tuan RS. Functional characterization of hypertrophy in chondrogenesis of human mesenchymal stem cells. Arthritis Rheum. 2008;58(5):1377-88. doi: 10.1002/art.23370. [PubMed:18438858].

10. Huang CY, Hagar KL, Frost LE, Sun Y, Cheung HS. Effects of cyclic compressive loading on chondrogenesis of rabbit bone-marrow derived mesenchymal stem cells. Stem Cells. 2004;22(3):313-23. doi: 10.1634/stemcells.22-3-313. [PubMed: 15153608].

11. Huang CY, Reuben PM, Cheung HS. Temporal expression patterns and corresponding protein inductions of early responsive genes in rabbit bone marrow-derived mesenchymal stem cells under cyclic compressive loading. Stem Cells. 2005;23(8):1113-21. doi: 10.1634/stemcells.2004-0202. [PubMed:15955834].

12. Mouw JK, Connelly JT, Wilson CG, Michael KE, Levenston ME. Dynamic compression regulates the expression and synthesis of chondrocytespecific matrix molecules in bone marrow stromal cells. Stem Cells. 2007;25(3):655-63. doi: 10.1634/stemcells.2006-0435. [PubMed: 17124008].

13. Cicha I, Goppelt-Struebe M. Connective tissue growth factor: contextdependent functions and mechanisms of regulation. Biofactors. 2009;35(2):200-8. doi:10.1002/biof.30. [PubMed:19449449].

14. Rich JT, Rosova I, Nolta JA, Myckatyn TM, Sandell LJ, McAlinden A Upregulation of Runx2 and Osterix during in vitro chondrogenesis of human adipose-derived stromal cells. Biochem Biophys Res Commun. 2008;372(1):230-5. doi: 10.1016/j.bbrc.2008.05.022. [PubMed: 18482578].

15. Klein-Nulend J, Roelofsen J, Sterck JG, Semeins CM, Burger EH. Mechanical loading stimulates the release of transforming growth factor-beta activity by cultured mouse calvariae and periosteal cells J Cell Physiol. 1995;163(1):115-9. doi: 10.1002/jcp.1041630113. [PubMed: 7896887].

16. Schumann D, Kujat R, Zellner J, Angele MK, Nerlich M, Mayr E, et al Treatment of human mesenchymal stem cells with pulsed low intensity ultrasound enhances the chondrogenic phenotype in vitro. Biorheology. 2006;43(3-4):431-43. [PubMed: 16912415].

17. Knippenberg M, Helder MN, Doulabi BZ, Semeins CM, Wuisman PI, Klein-Nulend J. Adipose tissue-derived mesenchymal stem cells acquire bone cell-like responsiveness to fluid shear stress on osteogenic stimulation. Tissue Eng. 2005;11(11-12):1780-8. doi: 10.1089/ten.2005.11.1780. [PubMed: 16411823].

18. Korstjens CM, van der Rijt RH, Albers GH, Semeins CM, Klein-Nulend J. Low-intensity pulsed ultrasound affects human articular chondrocytes in vitro. Med Biol Eng Comput. 2008;46(12):1263-70. doi 10.1007/s11517-008-0409-9. [PubMed: 18853213].

19. Li J, Wang J, Zou Y, Zhang Y, Long D, Lei L, et al. The influence of delayed compressive stress on TGF- $\beta 1$-induced chondrogenic differentiation of rat BMSCs through Smad-dependent and Smad-independent pathways. Biomaterials. 2012;33(33):8395-405. doi: 10.1016/j.biomaterials.2012.08.019.

20. Wang SE, Wu FY, Shin I, Qu S, Arteaga CL. Transforming growth factor \{beta\} (TGF-\{beta\})-Smad target gene protein tyrosine phosphatase receptor type kappa is required for TGF-\{beta\} function. Mol Cell Biol. 2005;25(11):4703-15. doi: 10.1128/MCB.25.11.4703-4715.2005. [PubMed: 15899872].

21. Leucht P, Kim JB, Amasha R, James AW, Girod S, Helms JA. Embryonic origin and Hox status determine progenitor cell fate during adult bone regeneration. Development. 2008;135(17):2845-54. doi 10.1242/dev.023788. [PubMed: 18653558].

22. Li Z, Kupcsik L, Yao SJ, Alini M, Stoddart MJ. Mechanical load modulates chondrogenesis of human mesenchymal stem cells through the TGF-beta pathway. J Cell Mol Med. 2010;14(6A):1338-46. doi: 10.1111/j.1582-4934.2009.00780.x. [PubMed: 19432813].

23. Schumann D, Kujat R, Nerlich M, Angele P. Mechanobiological conditioning of stem cells for cartilage tissue engineering. Biomed Mater Eng. 2006;16(4 Suppl):S37-52. [PubMed:16823112].

24. Cheng K, Xia P, Lin Q, Shen S, Gao M, Ren S, et al. Effects of lowintensity pulsed ultrasound on integrin-FAK-PI3K/Akt mechanochemical transduction in rabbit osteoarthritis chondrocytes. Ultrasound Med Biol. 2014;40(7):1609-18. doi:10.1016/j.ultrasmedbio.2014.03.002. [PubMed: 24742749].

25. Louw TM, Budhiraja G, Viljoen HJ, Subramanian A. Mechanotransduction of ultrasound is frequency dependent below the cavitation threshold. Ultrasound Med Biol. 2013;39(7):1303-19. doi: 10.1016/j.ultrasmedbio.2013.01.015. [PubMed: 23562015]

26. Yang Z, Sui L, Toh WS, Lee EH, Cao T. Stage-dependent effect of TGFbeta1 on chondrogenic differentiation of human embryonic stem cells. Stem Cells Dev. 2009;18(6):929-40. doi: 10.1089/scd.2008.0219. [PubMed: 18855519]. 